Short note

\title{
Microbial protein production determined by urinary allantoin and renal urea sparing in normal and low protein fed Corriedale sheep
}

\author{
Islamey TeBot ${ }^{\text {a*}}$, Alejandro BRitos ${ }^{\mathrm{a}}$, Jean Marie GodeAU ${ }^{\mathrm{b}}$, \\ Alberto CIRIO ${ }^{\mathrm{a}}$ \\ ${ }^{a}$ Departamento de Fisiología, Facultad de Veterinaria, Lasplaces 1550, \\ C.P. 11600 , Montevideo, Uruguay \\ ${ }^{\mathrm{b}}$ Chaire de Biochimie Normale et Pathologique, Faculté Vétérinaire de Liège, Belgium
}

(Received 11 January 2001; accepted 17 September 2001)

\begin{abstract}
The aim of the present study was to compare the amount of microbial N entering the duodenum and the efficiency of $\mathrm{N}$ utilisation for microbial protein synthesis in normal (NP, $17.4 \mathrm{~g} \mathrm{~N} / \mathrm{d}$ ) and low protein (LP, $7.5 \mathrm{~g} \mathrm{~N} / \mathrm{d}$ ) fed Corriedale sheep. Renal functional tests for urea handling studies, and determination of urinary allantoin as an indirect method to estimate the microbial protein production were used. Although the $\mathrm{N}$ intake was $57 \%$ lower in LP sheep, the microbial $\mathrm{N}$ production was not very different between both diets (NP: $3.99 \pm 0.01 \mathrm{vs}$. LP: $3.79 \pm 0.02 \mathrm{~g} / \mathrm{d}, P<0.05$ ). The efficiency of the microbial protein synthesis in the rumen, expressed as grams of microbial $\mathrm{N}$ per kg of digestible organic matter apparently digested in the rumen, was not statistically different for both diets. The urinary elimination of urea was reduced by $84 \%$ in LP sheep, essentially due to an important decrease in both renal plasma flow $(-63 \%)$ and glomerular filtration rate $(-71 \%)$. These haemodynamic changes would also reduce the filtered load and the urinary elimination of allantoin, thereby leading to an underestimation of the amount of microbial protein entering in the duodenum. Since the renal urea spared by the kidneys remains in the blood, it limits the drop of the available urea for ruminal recycling consecutive to a low nitrogen diet.
\end{abstract}

microbial protein / allantoin / urea / sheep

Résumé - Production de protéine microbienne mesurée par l'allantoïne urinaire et épargne rénale d'urée chez des moutons Corriedale en sous-alimentation protéique. L'objectif de cette étude a été de comparer la quantité d'azote microbien entrant dans le duodénum et l'efficacité de l'utilisation de l'azote pour la synthèse de protéines microbiennes, chez des moutons Corriedale soumis

*Correspondence and reprints

Tel.: (5982) 622 5640; fax: (5982) 628 0130, e-mail: itebot@montevideo.com.uy 
à un régime normoprotéique (NP, 17,4 g N/j) ou hypoprotéique (LP, 7,5 g N/j). Des tests de fonctionnement rénal pour étudier les transferts d'urée, et le dosage de l'allantoïne pour estimer la production de protéine microbienne ont été utilisés. Malgré une ingestion d'azote réduite de $57 \%$ chez les moutons LP, la production d'azote microbien n'a pas été très différente entre les deux régimes (NP: $3,99 \pm 0,01$ vs. LP: $3,79 \pm 0,02 \mathrm{~g} / \mathrm{j}, P<0,05)$. L'efficacité de la synthèse protéique microbienne dans le rumen, exprimée en grammes d'azote microbien par $\mathrm{kg}$ de matière organique apparemment digérée dans le rumen, n'a pas été statistiquement différente dans les deux régimes. L'élimination urinaire d'urée a été réduite de $84 \%$ chez les moutons LP, grâce essentiellement à une importante diminution du débit plasmatique rénal $(-63 \%)$ et de la filtration glomérulaire $(-71 \%)$. Ces modifications hémodynamiques réduisant également la charge filtrée et la quantité d'allantoïne éliminée, peuvent être responsables d'une sous estimation de la quantité de protéine microbienne entrant dans le duodénum. L'urée épargnée au niveau rénal restant dans le sang, limite la baisse de l'urée disponible pour le recyclage dans le rumen, observée lors des régimes pauvres en azote.

\section{protéine microbienne / allantoïne / urée / mouton}

\section{INTRODUCTION}

It is well known that in ruminants, endogenous urea is partly recycled in the forestomach. This process is nutritionally advantageous for ruminants because ruminal bacteria are able to use urea nitrogen to synthesize proteins that will be absorbed in the small intestine. When protein intake is restricted, renal elimination of urea is reduced by (a) a decreased filtered load of urea, consecutive to a reduction in renal plasma flow and glomerular filtration rate, and (b) an enhanced capacity for urea reabsorption from tubules and the renal pelvis [8]. This adaptive process prevents an excessive reduction of the blood urea pool.

A widely used method for the estimation of microbial protein production requires ruminal and duodenal cannulas [16] and microbial and digesta flow markers [11]. However, the microbial protein entering the duodenum can be estimated by quantification of urinary allantoin [21]. The nucleic acids synthesized by rumen microorganisms are enzymatically degraded to purine and pyrimidine bases which are absorbed; their final products are excreted in the urine with allantoin being in the greatest proportion [10]. Several authors have revealed a close relationship between microbial nucleic acids reaching the small intestine and the urinary excretion of purine derivatives, specially allantoin $[1,18]$.

Corriedale sheep, the main breed of the Uruguayan herd, graze different kinds of pastures with variable levels of nitrogen content throughout the year. To develop feeding strategies for sheep breeding on the basis of local foodstuffs, the objectives of this work were to investigate (a) the microbial protein production in Uruguayan Corriedale sheep under restricted nitrogen intake and (b) the importance of the renal mechanisms to reduce urea losses in this breed.

\section{MATERIALS AND METHODS}

Six non-pregnant non-lactating ewes weighing $38 \pm 2 \mathrm{~kg}$ were housed in metabolic cages and successively fed with normal (NP) and low (LP) protein rations (Tab. I), offered in four equal portions at $6 \mathrm{~h}$ intervals. Following a 30 days adaptation period to each diet, a retention catheter was placed into the urinary bladder and connected to a peristaltic pump (Masterflex, Cole Parmer Instrument Company, Niles, Illinois, USA) and an experimental period of eight days was started. During the first five days, a 24 h-urine sampling was performed, the urine was preserved $(250 \mathrm{~mL}$ 
Table I. Daily intakes (g/d) on normal (NP) and low protein (LP) diets (DOMI: digestible organic matter intake).

\begin{tabular}{lcc}
\hline & NP & LP \\
\hline Diet as-fed & 850.0 & 800.0 \\
Dry matter & 754.6 & 714.6 \\
Organic matter & 694.3 & 643.9 \\
Nitrogen & 17.4 & 7.5 \\
DOMI & $454.70 \pm 12.23$ & $372.58 \pm 25.34$ \\
\hline
\end{tabular}

$10 \%$ sulphuric acid per day) and a sample of $30 \mathrm{~mL}$ was frozen until analysed for allantoin.

To study the renal function, four test periods (10 min each, two in the morning and two in the afternoon) were carried out daily during the last three days of the experimental period for each animal and each diet. Both jugular veins were catheterized. One vein was used for perfusion and the other one for blood sampling. In order to measure renal plasma flow and the glomerular filtration rate, a primed constant-infusion $(0.5 \mathrm{~mL} / \mathrm{min})$ of $\mathrm{P}$-aminohippuric acid (PAH, $85 \mathrm{mg}$ and $8 \mathrm{mg} / \mathrm{mL} / \mathrm{min}$ ) and inulin (1.8 g and $70 \mathrm{mg} / \mathrm{mL} / \mathrm{min}$ ) (Sigma) in $0.9 \%$ saline, was made into a jugular vein, starting $20 \mathrm{~min}$ before the test periods. Bladder urine was collected for each period and a blood sample $(5 \mathrm{~mL}$ on heparin iodoacetate) was obtained at the midpoint of each period. Blood samples were centrifuged at $1350 \times g$ for $5 \mathrm{~min}$.

Plasma and urine were analysed for urea (urease kit, Wiener, Austria), inulin and PAH [15]. Renal plasma flow (as PAH clearance), glomerular filtration rate (as inulin clearance) and urea clearance were calculated as the product of urine flow and urinary concentration divided by plasma concentration. Fractional excretion of urea (as urea /inulin clearances) and filtered load of urea (as inulin clearance by plasma urea concentration) were determined. Allantoin was analysed in urine by the method of Young and Conway, modified by Fujihara [12]. Microbial protein synthesis was estimated according to the equation $y=\mathrm{e}^{(0.830+2.089 x)}$ proposed by Puchala and Kulasek [21], where $y=$ microbial $\mathrm{N}$ entering the duodenum and $x=$ urinary excretion of allantoin N. The efficiency of the microbial protein synthesis in the rumen was expressed as grams of microbial N per kilogram of digestible organic matter apparently digested in the rumen (DOMR). DOMR was assumed to be equal to $65 \%$ of digestible organic matter intake(DOMI) [2]. Statistical significance was evaluated by a Student paired $t$ test.

\section{RESULTS}

After one month on the experimental diets, the kidneys of LP sheep showed an increased ability to spare urea (Tab. II). Plasma urea level, renal plasma flow and glomerular filtration rate were reduced by the LP diet $(-45 \%,-63 \%$ and $-71 \%$ respectively) leading to a reduction in the filtered load of urea $(-88 \%)$ and in urea elimination $(-84 \%)$. Changes in fractional excretion of urea were not significant.

The daily urinary allantoin elimination was higher for NP than for the LP diet $(747.4 \pm 5.4$ vs. $676.4 \pm 7.6 \mathrm{mg} / \mathrm{d}$ respectively, $P<0.05$ ). The amount of microbial nitrogen entering the duodenum, estimated from urinary allantoin, was $3.99 \pm 0.01(\mathrm{NP})$ and $3.79 \pm 0.02(\mathrm{LP})$ microbial $\mathrm{N}$ g/day $(P$ $<0.05)$. DOMR was $0.30 \pm 0.02 \mathrm{~kg} /$ day for $\mathrm{NP}$ and $0.24 \pm 0.01$ for the LP diet. Although 
Table II. Plasma urea level and renal parameters on normal (NP) and low protein (LP) diets.

\begin{tabular}{lcc}
\hline \multicolumn{1}{c}{ Parameters } & NP diet & LP diet \\
\hline Plasma urea level $(\mathrm{mg} / \mathrm{mL})$ & $0.20 \pm 0.03$ & $0.09 \pm 0.03^{*}$ \\
Urine flow (mL/min) & $0.83 \pm 0.50$ & $0.80 \pm 0.30$ \\
Glomerular filtration rate $(\mathrm{mL} / \mathrm{min})$ & $69.5 \pm 10.2$ & $20.0 \pm 10.5^{*}$ \\
Renal plasma flow $(\mathrm{mL} / \mathrm{min})$ & $803 \pm 126$ & $300 \pm 70^{*}$ \\
Urea clearance $(\mathrm{mL} / \mathrm{min})$ & $46.9 \pm 20.6$ & $17.4 \pm 10.2$ \\
Filtered load of urea $(\mathrm{mg} / \mathrm{min})$ & $14.5 \pm 3.1$ & $1.7 \pm 0.9^{*}$ \\
Urea eliminated $(\mathrm{mg} / \mathrm{min})$ & $9.3 \pm 1.9$ & $1.5 \pm 0.9^{*}$ \\
Fractional excretion of urea & $0.61 \pm 0.07$ & $0.72 \pm 0.18$ \\
\hline
\end{tabular}

Values $=$ means $\pm \mathrm{SD}, n=6, * P<0.05$.

$\mathrm{N}$ intake was $57 \%$ lower in LP sheep, their efficiency of microbial protein synthesis was not different from that of NP sheep: $15.64 \pm 0.42$ (LP diet) vs. $13.52 \pm 0.71$ (NP diet) g microbial N/kg DOMR (NS).

\section{DISCUSSION}

As in previous results $[8,22]$, the kidneys of sheep adapted to restricted protein intake by reducing the amounts of urea eliminated in the urine. This decrease was larger than what we expected from the simple fall of the urea blood produced by the reduction of the $\mathrm{N}$ intake. A fall in the filtered load of urea, consecutive to important decreases in renal plasma flow, glomerular filtration rate and plasma urea level, was the main change observed. Changes in the tubular handling of urea (fractional excretion) induced by the LP diet were not found, in coincidence with our previous results concerning the Corriedale breed [23].

Allantoin elimination was higher for the NP diet. This result agrees with that of Chen et al. [7] who found that in sheep receiving constant energy but variable proteins, daily allantoin excretion is positively correlated with the cumulative N-retention, although the magnitude of variation in allantoin excretion is small.

The calculated values for daily microbial $\mathrm{N}$ production are lower than those most commonly found in the literature for similar feeding conditions. However, results of the same order as ours and obtained by the allantoin method have been reported: $5.7 \mathrm{~g}$ microbial $\mathrm{N} /$ day for an intake of $444 \mathrm{~g}$ DOMI/day and $45 \mathrm{~kg} \mathrm{BW}$ [6] and $10.9 \mathrm{~g}$ microbial N/kg DOMR/day, corresponding to $4.2 \mathrm{~g}$ microbial $\mathrm{N} /$ day and an intake of $590 \mathrm{~g} \mathrm{DOMI} /$ day, in sheep weighing $42 \mathrm{~kg}$ [20]. There is no clear explanation for these low values, but factors related to the quality of the ingredients of the diet could be evoked.

Our data on the efficiency of microbial protein synthesis in the rumen indicate that LP sheep were as productive as NP sheep. However, Puchala and Kulasek [21] reported the lowest rates of synthesis of rumen microbial protein in sheep fed low protein diets, independently of energy content.

Obara and Shimbayashi [19] found that the rumen is the main organ of the digestive tract where re-cycled urea is transferred in goats fed low protein diets. Both urea and allantoin are recycled in the rumen via saliva $[4,9]$ and, at least for urea, through the rumen wall [14], enhancing the availability of $\mathrm{N}$ for microbial protein synthesis. Allantoin and other purine derivatives are degraded by rumen bacteria $[13,17]$ and $\mathrm{N}$ could be used for microbial synthesis [3].

Net reabsorption of allantoin from tubular urine occurs in sheep, but this capacity is 
limited and appears to be saturated by a tubular load equivalent to endogenous allantoin production [5]. This means that, at a constant glomerular filtration rate, any addition of allantoin to the blood, once filtered at the glomeruli, will be eliminated in the urine. However, sheep fed low protein diets have reduced renal plasma flow and glomerular filtration rates so the filtered load and urine elimination of allantoin should also be reduced. Consequently, the amount of microbial protein entering the duodenum in LP sheep found in the present work may have been underestimated.

In conclusion, a $57 \%$ reduction in $\mathrm{N}$ intake did not affect the efficiency of microbial protein synthesis in the rumen of Corriedale ewes. Moreover, considering the presumable decrease in urinary allantoin elimination due to the renal heamodynamic response to low protein diets, the calculated values of this efficiency should be higher. Renal adaptation to low protein diets reduced by $84 \%$ the urinary losses of urea, thereby contributing to the blood urea pool and increasing its offer for ruminal recycling. The urinary allantoin method has been proved to be a useful tool as an indicator of microbial protein production, but when used in ruminants adapted to a low nitrogen intake, an underestimation of this production may occur.

\section{REFERENCES}

[1] Antoniewicz A.M., Heinemann W.W., Hanks E.M., The effect of changes in the intestinal flow of nucleic acids on allantoin excretion in sheep urine, J. Agric. Sci. Camb. 95 (1980) 395-400.

[2] Agricultural Research Council. The nutrient requirements of ruminant livestock (Suppl. 1). Commonwealth Agricultural Bureaux, Slough, United Kingdom, 1984.

[3] Belasco I.J., New nitrogen feed compounds for ruminants - a laboratory evaluation, J. Anim. Sci. 13 (1954) 601-610.

[4] Chen X.B, Hovell F.D.DeB., Ørskov E.R., Excretion of purine derivatives by ruminants: recycling of allantoin into the rumen via saliva and its fate in the gut, Br. J. Nutr. 63 (1990) 197-205.
[5] Chen X.B., Kyle D.J., Ørskov E.R., Hovell F.D.DeB., Renal clearance of plasma allantoin in sheep, Exp. Physiol. 76 (1991) 59-65.

[6] Chen X.B., Chen Y.K., Franflin M.F., Ørskov E.R., Shand W.J., The effect of feed intake and body weight on purine derivative excretion and microbial protein supply in sheep, J. Anim. Sci. 70 (1992) 1534-1542.

[7] Chen X.B., Chowdhury S.A., Hovell F.D.DeB., Ørskov E.R., Kyle D.J., Endogenous allantoin excretion in response to changes in protein supply in sheep, J. Nutr. 122 (1992) 2226-2232.

[8] Cirio A., Boivin R., Urea recycling from the renal pelvis in sheep: a study with 14C-urea, Am. J. Physiol. (Renal Fluid Electrolyte Physiol. 27) 258 (1990) F1196-F1202.

[9] Cirio A., Méot F., Delignette-Muller M.L., Boivin R., Determination of parotid urea secretion in sheep by means of ultrasonic flow probes and a multifactorial regression analysis, J. Anim. Sci. 78 (2000) 471-476.

[10] Condon R.J., Hatfield E.E., Metabolism of abomasally infused ribonucleic acid by sheep, J. Anim. Sci. 31 (1970) 1037.

[11] Faichney G.J., The use of markers to partition digestion within the gastrointestinal tract of ruminants, in: McDonald I.W., Warner A.C.I. (Eds.) Digestion and Metabolism in the Ruminant, The University of New England Publ. Unit., 1975, pp. 261-276.

[12] Fujihara T., Orskov E.R., Reeds P.J., Kyle D.J., The effect of protein infusion on urinary excretion of purine derivatives in ruminants nourished by intragastric nutrition, J. Agric. Sci. Camb. 109 (1987) 7-12.

[13] Gremer L., Meyer O., Characterization of xanthine dehydrogenase from the anaero bacterium Veillonella atypica and identification of a molybdopterin-cytosine-dinucleotide-containing molybdenum cofactor, Eur. J. Biochem. 238 (1996) 862-866.

[14] Houpt T.R., Houpt K.A., Transfer of urea nitrogen across the rumen wall, Am. J. Physiol. 214 (1968) 1296-1303.

[15] Lecoq R., Manuel d'analyses médicales et de biologie clinique, 2nd ed., Doin, Paris, France, 1967, 2410 pp.

[16] MacRae J.C., The use of re-entrant cannulae to partition digestive function within the gastrointestinal tract of ruminants, in: McDonald I.W., Warner A.C.I. (Eds.) Digestion and Metabolism in the Ruminant, The University of New England Publ. Unit., 1975, pp. 277-291.

[17] McAllan A.B., Smith R.H., Degradation of nucleic acids in the rumen, Br. J. Nutr. 29 (1973) 331-345. 
[18] McAllan A.B., Smith R.H., Degradation of nucleic acids derivatives by rumen bacteria in vitro, Br. J. Nutr. 29 (1973) 467-474.

[19] Obara Y., Shimbayashi K., The appearance of re-cycled urea in the digestive tract of goats during the final third of a once daily feeding of a low-protein ration, Br. J. Nutr. 44 (1980) 295-305.

[20] Pérez J.F., Balcells J., Guada J.A., Castrillo C., Rumen microbial production estimated either from urinary purine derivative excretion or from direct measurements of $15 \mathrm{~N}$ and purine bases as microbial markers: effect of protein source and rumen bacteria isolates, Anim. Sci. 65 (1997) 225-236.
[21] Puchala R., Kulasek G.W., Estimation of microbial protein flow from the rumen of sheep using microbial nucleic acid and urinary excretion of purine derivatives, Can. J. Anim. Sci. 72 (1992) 821-830.

[22] Rabinowitz L., Gunther R.A., Shoji E.S., Freedland R.A., Avery E.H., Effects of high and low protein diet on sheep renal function and metabolism, Kidney Int. 4 (1973) 188-207.

[23] Rodríguez M.N., Tebot I., Le Bas A., Nievas C., Leng L., Cirio A., Renal functions and urea handling in pregnant and lactating Corriedale ewes. Can. J. Anim. Sci. 76 (1996) 469-472. 